\title{
Determinan Struktur Modal Perusahaan Subsektor Konstruksi Bangunan di Bursa Efek Indonesia
}

\author{
Ninin Non Ayu Salmah, Sri Ermeila \\ Universitas PGRI Palembang, Universitas IBA Palembang \\ Correspondence Email: nininonayu@gmail.com, ermeilasri05@gmail.com
}

\begin{abstract}
The purpose of this research is to determine the effect of profitabity, asset structure and size on the capital structure of the Building Construction Sub-sector Company in the Indonesia Stock Exchange. This research is quantitative research Population are companies listed on the Building Construction Subsector on the Indonesia Stock Exchange, totaling 16 companies. The observation period is 2014 to 2018. The sample is determined based on non probability sampling with a purposive sampling technique. The total sample is 9 companies. The data used is secondary data. Data collection technique is documentation. Data analysis techniques are multiple linear regression with classical assumption, coefficient of determination and hypothesis test. The results of this research are simultaneously profitability, asset structure and size have a significant effect on capital structure, partially profitability has a negative and not significant effect on capital structure, partially the asset structure and size have positive and significant effect on capital structure, the regression equation is $Y=-4,527-0,011 X 1+0.082 X 2+0.414 X 3$ which shows profitability has a negative effect, asset structure and size has a positive effect, the coefficient of determination $34.3 \%$ which means the contribution of profitability, asset structure and size to capital structure is $38.8 \%$ while the remaining $61.2 \%$ is contributed by other variables not analyzed in this research.
\end{abstract}

Keywords: Asset Structure; Capital Structure; Size; Profitability

\section{PENDAHULUAN}

Sektor konstruksi bangunan telah berkembang pesat yang didorong peningkatan investasi swasta dan belanja pemerintah. Perkembangan sektor konstruksi bangunan berkaitan dengan pertumbuhan ekonomi berdasarkan permintaan dan penawaran pasar, struktur usaha pelaku usahan dan dukungan regulasi pemerintah. Sektor konstruksi bangunan memiliki peranan penting dalam perekonomian negara melalui penyediaan infrastruktur sebagai upaya untuk meningkatkan kesejahteraan masyarakat. Peningkatan kesejahteraan masyarakat melalui ketersediaan fasilitas aktivitas perekonomian secara fisik memungkinkan terjadinya kelancaran, kemudahan dan kecepatan penyampaian barang dan jasa yang pada akhirnya membuka peluang pekerjaan di bidang kontruksi bangunan dengan menyerap jumlah tenaga kerja yang cukup signifikan. Industri konstruksi memberikan kontribusi penting bagi perekonomian suatu negara melalui kemampuan menyerap tenaga kerja tidak terampil, semi terampil dan terampil (Sukandar, 2018).

Keberhasilan perusahaan-perusahaan yang bergerak di bidang konstruksi bangunan selain tergantung pada efektifitas manajemen perusahaan melaksanakan aktivitas operasionalnya juga memerlukan ruang untuk berkembang melalui ekspansi baik dalam bisnis inti maupun diversifikasi bisnis. Investasi berupa modal baik berasal dari pemilik perusahaan maupun pihak luar perusahaan. Kebutuhan modal dapat dipenuhi melalui penjualan saham perusahaan di pasar modal. Pasar modal adalah pasar abstrak, dimana yang diperjualbelikan adalah dana-dana jangka panjang yang keterikatannya dalam investasi lebih dari satu tahun (Widoatmojo, 2012). Pasar modal di Indonesia melalui Bursa Efek Indonesia memfasilitasi pihakpihak yang membutuhkan dana atau emiten dengan pihak-pihak yang memiliki kelebihan dana atau investor, termasuk perusahaan-perusahaan konstruksi bangunan. Fasilitasi tersebut memungkinkan pertumbuhan perusahaan menjadi lebih cepat dan berkembang dalam skala usaha yang lebih luas. Perusahaan-perusahaan yang telah tercatat pada Bursa efek Indoensia dikelompokkan dalam Klasifikasi Perusahaan Jasa Sektor Property, Real Estate dan Konstruksi Bangunan Sub sektor Konstruksi Bangunan.

Perusahaan konstruksi bangunan dihadapkan pada keputusan keuangan sebagai upaya meningkatkan nilai perusahaan. Salah satu keputusan keuangan adalah pendanaan perusahaan atau struktur modal. Struktur modal merupakan salah satu faktor yang menentukan nilai perusahaan (Putri, 2016). Keputusan pendanaan berkenaan dengan sumber maupun pengelolaannya. Keputusan pendanaan meliputi keputusan mengenai penetapan sumber dana yang yang diperlukan untuk mendanai investasi berupa hutang jangka panjang dan hutang jangka pendek juga modal sendiri serta penetapan tentang perimbangan pembelanjaan yang terbaik atau struktur modal yang optimum (Harjito dan Martono, 2014). Struktur modal memuat komponen utang 
dan modal. Struktur modal adalah perimbangan jumlah utang jangka pendek yang bersifat permanen, utang jangka panjang, saham preferen dan saham biasa (Sartono, 2015). Manajemen diharapkan dapat menyusun struktur modal dengan tepat agar tercapai perimbangan antara utang dan modal yang efektif dengan memperhatikan determinan atau faktor-faktor penentu struktur modal.

Brigham dan Houston (2011) menjelaskan terdapat beberapa faktor yang mempengaruhi struktur modal diantaranya, stabilitas penjualan, struktur aset, leverage operasi, tingkat pertumbuhan, profitabilitas, pajak, kendali, sikap manajemen, sikap pemberi pinjaman dan lembaga pemeringkat, kondisi pasar, kondisi internal perusahaan, dan fleksibilitas keuangan. Dengan demikian determinan struktur modal terdiri dari berbagai faktor diantaranya profitabilitas, struktur aset dan ukuran perusahaan. Hal ini diperkuat dengan hasil penelitian Suryaman (2016) menyatakan profitabilitas, struktur aktiva dan ukuran perusahaan berpengaruh signifikan terhadap struktur modal. Setiap perusahaan bertujuan memperoleh tingkat profitabilitas yang maksimal. Profitabilitas dapat diperoleh dari kemampuan perusahaan memperoleh laba melalui pengelolaan aktiva sehingga profitabiltas dalam penelitian ini direpresentasikan dengan return on asset (ROA). Pengembalian atas total aktiva (ROA) dihitung dengan cara membandingkan laba bersih yang tersedia untuk pemegang saham biasa dengan total (Brigham dan Houston, 2011). Perusahaan yang memiliki laba yang tinggi lebih memilih memaksimalkan penggunaan laba ditahan daripada menggunakan utang untuk pendanaan sehingga diprediksi hubungan antara profitabilitas dengan struktur modal adalah negatif. Hal ini diperkuat dengan hasil penelitian Denziana dan Yunggo (2017) yang menyatakan profitabilitas berpengaruh negatif dan signifikan terhadap struktur modal.

Struktur aset dipertimbangkan sebagai jaminan perusahaan kepada pihak eksternal ketika perusahaan menggunakan utang sebagai sumber pendanaan. Struktur aset atau struktur aktiva adalah perimbangan atau perbandingan antara aktiva tetap dan total aktiva (Brigham dan Houston, 2011). Perusahaan yang memiliki aset tetap dalam jumlah besar dapat menggunakan utang dalam jumlah besar hal ini disebabkan karena dari skalanya perusahaan besar akan lebih mudah mendapatkan akses ke sumber dana dibandingkan dengan perusahaan kecil, kemudian besarnya aset tetap dapat digunakan sebagai jaminan utang perusahaan (Sartono, 2015). Besarnya aset tetap yang dimiliki perusahaan dan dijadikan jaminan memudahkan perusahaan mendapatkan sumber pendanaan selain modal sendiri sehingga diprediksi hubungan antara struktur aset dan struktur modal adalah positif. Hal ini diperkuat dengan hasil penelitian Sari, Djumahir dan Djazuli (2015) yang menyatakan struktur aset berpengaruh positif terhadap struktur modal.

Ukuran perusahaan mencerminkan besar atau kecilnya perusahaan berdasarkan total aset. Semakin besar ukuran suatu perusahaan, kecenderungan menggunakan modal eksternal juga semakin besar karena perusahaan besar membutuhkan dana yang besar pula untuk menunjang operasionalnya, dan salah satu alternatif pemenuhannya adalah dengan modal eksternal apabila modal sendiri sudah tidak mencukupi (Septiani dan Suaryana, 2018). Perusahaan dengan ukuran yang lebih besar akan lebih mudah memperoleh dana dari pihak eksternal. Hal ini disebabkan perusahaan dianggap kompetitif melalui aktivitas operasional yang didukung besarnya aset lancar dan kemudahan memperoleh jaminan berdasarkan aset tetap sehingga diprediksi hubungan antara ukuran aset dengan struktur modal adalah positif. Hal ini diperkuat dengan hasil penelitian Ratri dan Christianti (2017) yang menyatakan ukuran perusahaan berpengaruh positif terhadap struktur modal. Penelitian ini bertujuan untuk mengetahui pengaruh variabel profitabilitas, struktur perusahaan dan ukuran perusahaan terhadap struktur modal Perusahaan Sub sektor Konstruksi Bangunan di Bursa Efek Indonesia. Hipotesis yang diajukan dalam penelitian ini adalah 1)secara simultan profitabilitas, struktur aktiva dan ukuran perusahaan berpengaruh signifikan terhadap struktur modal Perusahaan Sub sektor Konstruksi Bangunan di Bursa Efek Indonesia 2)secara parsial, profitabilitas berpengaruh negatif dan signifikan terhadap struktur modal Perusahaan Sub sektor Konstruksi Bangunan di Bursa Efek Indonesia 3)secara parsial, struktur aset berpengaruh positif dan signifikan terhadap struktur modal Perusahaan Sub sektor Konstruksi Bangunan di Bursa Efek Indonesia dan 4)secara parsial, ukuran perusahaan berpengaruh positif dan signifikan terhadap struktur modal Perusahaan Sub sektor Konstruksi Bangunan di Bursa Efek Indonesia.

\section{METODE PENELITIAN}

Penelitian ini merupakan penelitian kuantitatif. Penelitian dengan metode kuantitatif menekankan pada pengujian teori-teori melalui pengukuran variabel-variabel penelitian dengan angka dan melakukan analisis 
data dengan prosedur statistik. (Yanuardi, Hadiwidjojo dan Sumiati, 2014). Desain penelitian ini adalah penelitian eksplanatori. Penelitian eksplanatori dimaksudkan untuk menjelaskan suatu generalisasi sampel terhadap populasinya atau menjelaskan hubungan, perbedaan atau pengaruh suatu variabel dengan variabel lain (Bungin, 2011). Variabel penelitian adalah struktur aset, likuiditas, profitabilitas sebagai variabel independen sedangkan struktur modal sebagai variabel dependen. Definisi operasionalisasi variabel dalam penelitian ini meliputi 1) )profitabilitas direpresentasikan dengan return on asset (ROA) menunjukkan kemampuan perusahaan dengan menggunakan seluruh aset yang dimiliki untuk menghasilkan laba setelah pajak (Sudana, 2012) 2)struktur asset, merupakan perimbangan atau perbandingan antara aset tetap dan total aset (Weston dan Copeland, 2008) 3)ukuran perusahaan, adalah besar kecilnya perusahaan yang diukur dengan total aktiva perusahaan menggunakan logaritma total aktiva (Hartono, 2014) dan 4)struktur modal, direpresentasikan dengan debt to equity ratio (DER) yang memberi gambaran perbandingan antara total hutang dengan modal sendiri (Sitanggang, 2014).

Populasi penelitian ini adalah perusahaan-perusahaan yang tercatat pada Subsektor Konstruksi Bangunan di Bursa Efek Indonesia yang berjumlah 16 perusahaan. Periode pengamatan selama 5 tahun yaitu tahun 2014 sampai dengan 2018. Penetapan periode pengamatan dianggap representatif terhadap tren yang dibutuhkan dalam analisis. Sampel ditentukan berdasarkan non probability sampling dengan teknik purposive sampling. Kriteria penentuan sampel adalah 1) perusahaan mempublikasikan laporan keuangan perusahaan tiap tahun dan memiliki kelengkapan data selama periode pengamatan 2) perusahaan bukan merupakan anak perusahaan dari perusahaan lain. Berdasarkan kriteria tersebut diperoleh 9 perusahaan sebagai sampel yaitu Acset Indonusa Tbk dengan kode saham ACST, Adhi Karya (Persero) Tbk (ADHI), Nusa Konstruksi Enjiniring Tbk (DGIK), Nusa raya Cipta Tbk (NRCA), PP Persero Tbk (PTPP), Surya Semesta Internusa Tbk (SSIA), Total Bangun Persada Tbk (TOTL), Wijaya karya Tbk (WIKA) dan Waskita Karya Tbk (WSKT).

Sumber data diperoleh dari www.idx.co.id berupa data sekunder yang meliputi laporan keuangan perusahaan Subsektor Konstruksi Bangunan. Data dikumpulkan dengan teknik dokumentasi berupa data total aktiva tetap, total aktiva, total aktiva, laba bersih setelah pajak dan total hutang. Data diolah dengan dengan SPSS (Statistical Program and Service Solution Version 22 for Windows). Penelitian ini menggunakan teknik analisis data statistik inferensial yang terdiri dari analisis regresi linear berganda, analisis koefisien determinasi dan pengujian hipotesis. Pengaruh variabel independen terhadap variabel dependen dianalisis dengan regresi linear berganda. Persamaan regresi linear berganda yang dibentuk adalah $\mathrm{Y}=\mathrm{a}+\mathrm{b}_{1} \mathrm{X}_{1}+\mathrm{b}_{2} \mathrm{X}_{2}+\mathrm{b}_{3} \mathrm{X}_{3}$ dimana a adalah konstanta, $\mathrm{b}_{1}, \mathrm{~b}_{2}$ dan $\mathrm{b}_{3}$ adalah koefisien regresi. $\mathrm{X}_{1}$ adalah variabel profitabilitas, $\mathrm{X}_{2}$ adalah struktur aset, $\mathrm{X}_{3}$ adalah ukuran perusahaan dan $\mathrm{Y}$ adalah struktur modal.

Analisis regresi linear berganda mempersyaratkan adanya uji asumsi klasik terhadap data penelitian yang meliputi uji normalitas, uji multikolineritas, uji heteroskedastisitas dan uji autokorelasi. Uji normalitas adalah untuk mengetahui data berdistribusi normal atau tidak, dengan uji Kolmogorov-Smirnov. Kriteria penerimaan pada uji Kolmogorov -Smirnov adalah jika nilai Asymp. Sig lebih besar dari 0,05 maka data berdistribusi normal sedangkan jika nilai Asymp. Sig lebih kecil dari 0,05 maka data tidak berdistribusi normal. Uji multikolinearitas adalah untuk mengetahui terjadi tidaknya hubungan linear antara variabel bebas, dengan melihat nilai tolerance dan value inflation factor (VIF). Kriteria penerimaan uji multikolinearitas adalah jika nilai tolerance lebih besar dari 0,10 dan VIF kurang dari 10 maka tidak terjadi gejala multikolinearitas dalam model regresi sedangkan jika nilai tolerance lebih kecil dari 0,10 dan VIF lebih dari 10 maka terjadi gejala multikolinearitas dalam model regresi.

Uji heterokedastisitas adalah untuk mengetahui ada tidaknya ketidaksamaan varian dari residual pada satu pengamatan dengan pengamatan lainnya, dengan metode rank spearman. Kriteria penerimaan adalah jika nilai Sig. (2-tailed) lebih besar dari 0,05 maka tidak terdapat gejala heteroskedastisitas dalam model regresi sedangkan jika nilai Sig. (2-tailed) lebih kecil dari 0,05 maka terdapat gejala heteroskedastisitas dalam model regresi. Uji autokorelasi adalah untuk mengetahui ada tidaknya korelasi yang terjadi pada satu pengamatan lainnya, dilakukan dengan uji Durbin-Watson dengan kriteria penerimaan jika nilai Durbin Watson terletak antara dU dan (4-dU) maka tidak terdapat gejala autokorelasi. Analisis koefisien determinasi adalah untuk mengetahui kontribusi variabel independen terhadap variabel dependen dianalisis dengan koefisien determinasi. Signifikansi pengaruh variabel independen terhadap variabel dependen baik secara simultan maupun parsial diuji dengan pengujian hipotesis. Pengujian hipotesis secara simultan 
dengan uji $\mathrm{F}$ dan parsial dengan uji t menggunakan level of significant sebesar $5 \%$ atau 0,05 . Kriteria penerimaan hipotesis adalah jika level of significant lebih dari 0,05 maka hipotesis nol diterima sedangkan jika level of significant kurang dari 0,05 maka hipotesis nol ditolak dan hipotesis alternatif diterima.

\section{HASIL DAN PEMBAHASAN}

Variabel penelitian dideskripsikan dalam bentuk nilai rata-rata yang dapat digunakan sebagai informasi keterwakilan data penelitian. Tabel berikut ini menyajikan nilai rata-rata variabel penelitian berdasarkan sampel penelitian,

Tabel 1

Nilai Rata-Rata Variabel Penelitian

\begin{tabular}{lrrrr}
\hline Kode Saham & \multicolumn{3}{c}{ Rata-Rata } \\
& Profitabilitas & \multicolumn{1}{c}{ Struktur Aset } & \multicolumn{1}{c}{ Ukuran Perusahaan } & \multicolumn{1}{c}{ Struktur Modal } \\
\hline ACST & 3,20 & 0,13 & 3.813 .206 .600 .000 & 2,20 \\
ADHI & 2,09 & 0,06 & 20.797 .638 .200 .000 & 3,48 \\
DGIK & 0,95 & 0,02 & 328.107 .600 .000 & 0,26 \\
NRCA & 7,93 & 0,05 & 2.130 .691 .800 .000 & 0,91 \\
PTPP & 3,64 & 0,13 & 31.073 .826 .200 .000 & 2,77 \\
SSIA & 6,06 & 0,16 & 7.190 .587 .000 .000 & 0,96 \\
TOTL & 6,87 & 0,06 & 2.901 .843 .800 .000 & 2,13 \\
WIKA & 3,37 & 0,12 & 33.838 .782 .200 .000 & 2,22 \\
WSKT & 3,64 & 0,06 & 176.849 .562 .600 .000 & 3,04 \\
Rata-Rata & 4,19 & 0,09 & $30.991 .582 .888 .888,90$ & 2,00 \\
\hline
\end{tabular}

Sumber : data diolah, 2019

Rata-rata profitabilitas sampel penelitian adalah 4,19\% dengan besaran yang bervariasi. Rata-rata probabilitas perusahaan dimulai dari rata-rata terendah sebesar $0,95 \%$ yang diperoleh PT Nusa Konstruksi Enjiniring Tbk hingga rata-rata tertinggi sebesar 7,93\% diperoleh PT. Waskita Karya Tbk sehingga jarak rata-rata profitabilitas perusahaan tertinggi dan terendah sebesar 6,98\%. Tingkat probabilitas yang di bawah nilai rata-rata sampel perusahaan diperoleh oleh 6 perusahaan dan sebanyak 3 perusahaan berada di atas rata-rata sampel perusahaan. Rata-rata struktur aset sampel penelitian adalah 0,09 dengan besaran yang bervariasi. Rata-rata struktur aset perusahaan dimulai dari rata-rata terendah sebesar 0,02 yang diperoleh PT Nusa Konstruksi Enjiniring Tbk hingga rata-rata tertinggi sebesar 0,16 diperoleh PT. Surya Semesta Internusa Tbk sehingga jarak rata-rata struktur aset perusahaan tertinggi dan terendah sebesar 0,14. Struktur aset di bawah nilai rata-rata sampel perusahaan diperoleh oleh 5 perusahaan dan sebanyak 4 perusahaan berada di atas rata-rata sampel perusahaan.

Rata-rata ukuran perusahaan sampel penelitian adalah Rp 30.991.582.888.888,90 dengan besaran yang bervariasi. Rata-rata ukuran perusahaan dimulai dari rata-rata terendah sebesar Rp 328.107.600.000,00 yang diperoleh PT Nusa Konstruksi Enjiniring Tbk hingga rata-rata tertinggi sebesar Rp 176.849.562.600.000,00 yang diperoleh PT. Waskita Karya Tbk sehingga jarak rata-rata ukuran perusahaan cukup besar yaitu Rp 176.521.455.000.000,00. Ukuran perusahaan di bawah nilai rata-rata sampel perusahaan diperoleh oleh 8 perusahaan dan sebanyak 1 perusahaan berada di atas rata-rata sampel perusahaan. Rata-rata struktur modal sampel penelitian adalah 2,00 kali dengan besaran yang bervariasi. Rata-rata struktur modal perusahaan dimulai dari rata-rata terendah sebesar 0,26 kali yang diperoleh PT Nusa Konstruksi Enjiniring Tbk hingga rata-rata tertinggi sebesar 3,48 kali diperoleh PT. Adhi Karya Tbk sehingga jarak rata-rata struktur aset perusahaan tertinggi dan terendah sebesar 3,22 kali. Struktur modal di bawah nilai rata-rata sampel perusahaan diperoleh oleh 3 perusahaan dan sebanyak 6 perusahaan berada di atas rata-rata sampel perusahaan

\section{Uji Asumsi Klasik}

Sebelum menggunakan analisis regresi linear berganda terlebih dahulu dilakukan uji asumsi klasik. Hasil uji normalitas disajikan pada tabel berikut ini. 
Tabel 2

Hasil Uji Normalitas

\begin{tabular}{lc}
\hline & Unstandardized Residual \\
\hline Kolmogorov-Smirnov Z & 0,054 \\
Asymp. Sig. (2-tailed) & 0,323 \\
\hline
\end{tabular}

Sumber : data diolah, 2019

Uji normalitas data menghasilkan nilai Asymp. Sig (2-tailed) sebesar 0,323 atau lebih besar dari 0,05. Hasil tersebut menyimpulkan data berdistribusi normal dan data dapat digunakan dalam model regresi. Hasil uji multikolinearitas disajikan pada tabel berikut ini.

Tabel 3

Hasil Uji Multikolineritas

\begin{tabular}{lcc}
\hline & \multicolumn{2}{c}{ Collinearity Statistics } \\
& Tolerance & VIF \\
\hline Profitabilitas & 0,999 & 1,001 \\
Struktur Aset & 0,680 & 1,470 \\
Ukuran Perusahaan & 0,680 & 1,470 \\
\hline S
\end{tabular}

Sumber : data diolah, 2019

Uji multikolinearitas menghasilkan nilai tolerance masing-masing variabel penelitian lebih dari 0,10 yaitu variabel profitabilitas sebesar 0,999, stuktur aset sebesar 0,680 dan ukuran perusahaan sebesar 0.680 sedangkan nilai VIF masing-masing variabel penelitian kurang dari 10 yaitu variabel profitabilitas sebesar 1,001, struktur aset 1,470 dan ukuran perusahaan sebesar 1,470. Hasil tersebut menyimpulkan tidak terjadi gejala multikolinearitas dan data dapat digunakan dalam model regresi. Hasil uji heterokedastisitas disajikan pada tabel berikut ini.

Tabel 4

Hasil Uji Heteroskedastisitas

$\begin{array}{ll}\text { Profitabilitas } & 0,539 \\ \text { Struktur Perusahaan } & 0,828 \\ \text { Ukuran Perusahaan } & 0,563\end{array}$

Sumber : data diolah, 2019

Uji heterokedastisitas dengan metode rank spearman menghasilkan nilai Sig. masing-masing variabel independen lebih dari 0,05 yaitu variabel profitabilitas sebesar 0,539, struktur asset sebesar 0,828 dan ukuran perusahaan sebesar 0,563. Hasil tersebut menyimpulkan tidak terjadi gejala heteroskedatisitas dan data dapat digunakan dalam model regresi. Hasil uji autokorelasi disajikan pada Tabel 5 berikut ini.

Tabel 5

Hasil Uji Autokorelasi

\begin{tabular}{ll} 
& Nilai \\
\hline Durbin-Watson & 1,852 \\
\hline Sumber : data diolah, 2019
\end{tabular}

Uji autokorelasi menghasilkan nilai Durbin-Watson (DW) sebesar 1,852 atau lebih dari batas atas (DU) sebesar 1,6662 dan kurang dari 4-DW sebesar 2,148. Hasil tersebut menyimpulkan tidak terjadi autokorelasi pada data dan data dapat digunakan dalam model regresi.

\section{Analisis Regresi Linear Berganda}

Analisis regresi linear berganda digunakan untuk mengetahui pengaruh variabel independen terhadap variabel dependen. Tabel berikut ini menyajikan hasil persamaan regresi linear berganda. 
Tabel 6

Hasil Persamaan Regresi Berganda

Constant

Profitabilitas

Struktur Aset

Ukuran Perusahaan

Sumber : data diolah, 2019
Unstandarized Coefficient B

$-4,527$

$-0,011$

0,082

0,414

Persamaan regresi yang diperoleh adalah $\mathrm{Y}=-4,527-0,011 \mathrm{X}_{1}+0,082 \mathrm{X}_{2}+0,414 \mathrm{X}_{3}$. Nilai konstanta a sebesar $-4,527$ berarti struktur modal sebesar -4,527 jika perusahaan tidak menghasilkan laba sebagai pencerminan tingkat profitabilitas dan tidak memiliki aktiva baik aktiva lancar maupun aktiva tetap sebagai pencerminan struktur aset dan ukuran perusahaan. Koefisien regresi $b_{1}$ dengan variabel independen profitabilitas sebesar $-0,011$ berarti jika profitabilitas meningkat sebesar 1 satuan maka struktur modal menurun sebesar 0,011 dan sebaliknya jika profitabilitas menurun sebesar 1 satuan maka struktur modal meningkat sebesar 0,011 satuan dimana variabel struktur aset dan ukuran perusahaan konstan. Dengan demikian pengaruh variabel profitabilitas terhadap struktur modal Perusahaan Sub sektor Konstruksi Bangunan di Bursa Efek Indonesia adalah negatif. Perusahaan yang memiliki tingkat profitabilitas yang tinggi akan mengurangi ketergantungannya pada pihak eksternal perusahaan karena profit perusahaan yang tinggi memungkinkan perusahaan untuk mendanai perusahaannya sendiri melalui laba ditahan sehingga dapat diprediksikan bahwa profitabilitas memiliki hubungan negatif terhadap struktur modal (Dharmadi dan Putri, 2018)

Koefisien regresi $b_{2}$ dengan variabel independen struktur aset sebesar 0,082 berarti jika struktur aset meningkat sebesar 1 satuan maka struktur modal juga meningkat sebesar 0,082 satuan dan sebaliknya jika struktur aset menurun sebesar 1 satuan maka struktur modal juga menurun sebesar 0,082 satuan dimana variabel profitabilitas dan ukuran perusahaan konstan. Dengan demikian pengaruh variabel struktur aset terhadap struktur modal Perusahaan Sub sektor Konstruksi Bangunan di Bursa Efek Indonesia adalah positif. Semakin tinggi struktur aktiva yang merupakan perbandingan aktiva lancar dengan aktiva tetap, maka struktur modal perusahaan juga akan semakin tinggi (Deviani dan Sudjarni, 2018). Koefisien regresi $b_{3}$ dengan variabel independen ukuran perusahaan sebesar 0,414 berarti jika ukuran perusahaan meningkat sebesar 1 satuan maka struktur modal juga berubah 0,414 dan sebaliknya jika ukuran perusahaan menurun sebesar 1 satuan maka struktur modal juga menurun sebesar 0,414 satuan dimana variabel profitabilitas dan ukuran perusahaan konstan. Dengan demikian pengaruh variabel ukuran perusahaan terhadap struktur modal Perusahaan Sub sektor Konstruksi Bangunan di Bursa Efek Indonesia adalah positif. Ukuran perusahaan akan berpengaruh terhadap struktur modal dengan didasarkan pada kenyataan bahwa semakin besar ukuran perusahaan, terdapat kecenderungan untuk menggunakan jumlah pinjaman yang lebih besar (Maulina, Nuzula dan Nurlaily, 2018)

\section{Koefisien Determinasi}

Analisis koefisien korelasi dilakukan untuk mengetahui berapa besar kontribusi variabel independen terhadap variabel dependen dalam model yang dianalisis. Tabel berikut ini menyajikan hasil analisis koefisien determinasi.

Tabel 7

Koefisien Determinasi

\begin{tabular}{ccc}
\hline$R$ & $R$ Square & Adjusted $R$ Square \\
\hline 0,623 & 0,388 & 0,343 \\
\hline
\end{tabular}

Sumber : data diolah, 2019

Koefisien determinasi menghasilkan nilai adjusted $R$ square sebesar 34,3\% yang berarti kontribusi variabel independen profitabilitas, stuktur aset dan ukuran perusahan terhadap variabel dependen struktur modal sebesar 38,8\% sedangkan sisanya sebesar $61,2 \%$ dikontribusikan oleh variabel lain yang tidak dianalisis dalam penelitian ini. Variabel tersebut diantaranya likuiditas, risiko, pertumbuhan penjualan,. Penelitian Hardanti dan Gunawan (2010) menghasilkan sebesar 37,8\% variasi perubahan struktur modal 
dapat dijelaskan oleh variasi perubahan dari ukuran perusahaan, likuiditas, profitabilitas, risiko dan pertumbuhan penjualan serta penelitian Guna dan Sampurno (2018) menghasilkan 43,3\% variasi struktur modal mampu dijelaskan oleh profitabilitas, likuiditas, struktur aktiva, pertumbuhan penjualan, dan ukuran perusahaan.

\section{Pengujian Hipotesis}

Pengujian hipotesis dilakukan dengan uji F (ANOVA) untuk uji simultan dan uji t untuk uji parsial. Uji simultan menguji signifikansi pengaruh variabel independen ukuran perusahaan, struktur aset dan profitabilitas terhadap struktur modal secara simultan. Tabel berikut ini menyajikan hasil uji simultan.

Tabel 8

Hasil Uji F (ANOVA)

\begin{tabular}{lcc}
\hline & Sig. & \\
\hline Regression & 0.002
\end{tabular}

Sumber : data diolah, 2019

Uji F menghasilkan nilai Sig. sebesar 0,002 atau kurang dari 0,05. Hasil tersebut memberikan kesimpulan bahwa secara simultan profitabilitas, struktur aset dan ukuran perusahaan berpengaruh signifikan terhadap struktur modal. Hasil penelitian ini konsisten dengan penelitian Batubara, Topowijoyo dan Zahroh (2017) menyatakan terdapat pengaruh secara simultan antara variabel struktur aktiva, ukuran perusahaan dan profitabilitas terhadap struktur modal. Uji parsial menguji signifikansi pengaruh variabel independen profitabilitas, struktur asset dan ukuran perusahaan terhadap struktur modal secara parsial. Tabel berikut ini menyajikan hasil uji parsial.

Tabel 9

Hasil Uji t

\begin{tabular}{lc}
\hline & Sig. \\
\hline Profitabilitas & 0,694 \\
Struktur Aset & 0,002 \\
Ukuran Perusahaan & 0,000 \\
\hline
\end{tabular}

Sumber : data diolah, 2019

Uji t dengan variabel bebas profitabilitas menghasilkan nilai Sig. sebesar 0,694 atau kurang dari 0,05. Hasil tersebut memberikan kesimpulan bahwa secara parsial, profitabilitas berpengaruh negatif dan tidak signifikan terhadap struktur modal. Pengaruh negatif yang terjadi sesuai dengan hasil persamaan regresi berganda pada koefisien regresi $b_{1}$ yang memberikan nilai negatif sebesar $-0,011$. Penelitian ini konsisten dengan penelitian Dewiningrat dan Mustanda (2018) yang menghasilkan profitabilitas berpengaruh negatif dan tidak signifikan terhadap struktur modal tetapi tidak konsisten dengan penelitian Shofiyuddin (2015) serta penelitian Guna dan Sampurno (2018) yang menghasilkan profitabilitas berpengaruh signifikan terhadap struktur modal. Uji t dengan variabel bebas struktur aset perusahaan menghasilkan nilai Sig. sebesar 0,002 atau kurang dari 0,05. Hasil tersebut memberikan kesimpulan bahwa secara parsial struktur aset berpengaruh positif dan signifikan terhadap struktur modal. Pengaruh positif yang terjadi sesuai dengan hasil persamaan regresi berganda pada koefisien regresi $b_{2}$ yang memberikan nilai positif sebesar 0,082 . Penelitian ini konsisten dengan penelitian Suryaman (2016) yang menghasilkan struktur aktiva berpengaruh positif dan signifikan terhadap struktur modal tetapi tidak konsisten dengan penelitian Deviani dan Sudjarni (2018) yang menghasilkan struktur aktiva berpengaruh negatif dan tidak signifikan terhadap struktur modal.

Uji t dengan variabel bebas ukuran perusahaan menghasilkan nilai Sig. sebesar 0,000 atau kurang dari 0,05. Hasil tersebut memberikan kesimpulan bahwa secara parsial ukuran perusahaan berpengaruh positif dan signifikan terhadap struktur modal. Pengaruh positif sesuai dengan hasil persamaan regresi berganda pada koefisien regresi $b_{3}$ yang memberikan nilai positif sebesar 0,414. Septiani dan Suaryana (2018) yang menghasilkan ukuran perusahaan berpengaruh positif pada struktur modal tetapi tidak konsisten dengan penelitian Krisnanda dan Wiksuana (2015) yang menghasilkan ukuran perusahaan mempunyai pengaruh negatif dan tidak signifikan terhadap struktur modal. 


\section{SIMPULAN}

Berdasarkan hasil penelitian dapat disimpulkan 1)secara simultan, profitabilitas, struktur aset dan ukuran perusahaaan berpengaruh signifikan terhadap struktur modal Perusahaan Sub sektor Konstruksi Bangunan di Bursa Efek Indonesia 2) secara parsial, profitabilitas berpengaruh negatif dan tidak signifikan terhadap struktur modal Perusahaan Subsektor Konstruksi Bangunan di Bursa Efek Indonesia 3)secara parsial, struktur aset berpengaruh positif dan signifikan terhadap struktur modal Perusahaan Sub sektor Konstruksi Bangunan di Bursa Efek Indonesia dan 4)secara parsial, ukuran perusahaan berpengaruh positif dan signifikan terhadap struktur modal Perusahaan Sub sektor Konstruksi Bangunan di Bursa Efek Indonesia. Penelitian ini juga memperoleh persamaan regresi yaitu $Y=-4,527-0,011 X_{1}+0,082 X_{2}+0,414 X_{3}$ yang menunjukkan variabel profitabilitas dengan koefisien regresi $b_{1}$ berpengaruh negatif terhadap struktur modal sedangkan struktur aset dengan koefisien regresi $b_{2}$ dan ukuran perusahaan dengan koefisien regresi $b_{3}$ berpengaruh positif terhadap struktur modal Perusahaan Sub sektor Konstruksi Bangunan di Bursa Efek Indonesia. Koefisien determinasi sebesar 34,3\% yang berarti kontribusi variabel profitabilitas, stuktur aset dan ukuran perusahan terhadap struktur modal Perusahaan Sub sektor Konstruksi Bangunan di Bursa Efek Indonesia sebesar 38,8\% sedangkan sisanya sebesar 61,2\% dikontribusikan oleh variabel lain yang tidak dianalisis dalam penelitian ini.

\section{DAFTAR PUSTAKA}

Batubara, R. A. P., Topowijoyo, \& Zahroh, Z. A. (2017). Pengaruh struktur aktiva, ukuran perusahaan dan profitabilitas terhadap struktur modal (studi pada perusahaan makanan dan miniman yang terdaftar di Bursa Efek Indonesia tahun 2012-2015). Jurnal Administrasi Bisnis,50(4), 1-9.

Brigham, E.F., \& Houston, J. F. (2011). Dasar-dasar manajemen keuangan. Jakarta : Salemba Empat.

Bungin, B. (2011). Metodologi penelitian kualitatif. Jakarta : PT. Raja Grafindo

Denziana, A., \& Yunggo, E.. D. (2017). Pengaruh profitabilitas, struktur aktiva dan ukuran perusahaan terhadap struktur modal perusahaan pada perusahaan real estate and property yang terdaftar di Bursa Efek Indonesia Tahun 2015. Jurnal Akuntansi \& Keuangan, 8(1), 51-67.

Deviani, M. Y., \& Sudjarni, L. K. (2018). Pengaruh tingkat pertumbuhan, struktur aktiva, profitabilitas dan likuiditas terhadap struktur modal perusahaanb pertambangan di BEI. E-Jurnal Manajemen Unud, 7(3), 1222-1254

Dewiningrat, A. I., \& Mustanda, I. K. (2018) Pengaruh likuiditas, profitabilitas, pertumbuhan penjualan dan struktur aset terhadap struktur modal. E-Jurnal Manajemen Unud, 7 (7), 3471-3501.

Dharmadi, I. K. Y., \& Putri, I. G. A. M. A. D., (2018). Pengaruh struktur aset, profitabilitas, operating leverage, likuiditas terhadap struktur modal perusahaan consumer goods di BEI. Jurnal Akuntansi Unud, 24(3). 1858-1879

Guna, M. A., \& Sampurno, R. D. (2018). Analisis faktor-faktor yang mempengaruhi struktru modal (studi kasus pada perusahaan makanan dan minuman yang terdaftar di BEI periode 2012-2016). Diponegoro Journal of Management,7(2), 1-12.

Hardanti, S. \& Gunawan, B. (2010). Pengaruh size, likuiditas, profitabilitas, risiko dan pertumbuhan penjualan terhadap struktur modal (studi empiris pada perusahaan manufaktur di Bursa Efek Indonesia). Jurnal Akuntansi dan Investasi, 11(2),148-165.

Harjito, A., \& Martono. (2014). Manajemen keuangan. Yogyakarta,:Ekonisia.

Hartono, J. (2014). Teori portofolio dan analisis investasi. Yogyakarta:BPFE.

Krisnanda, P. H., \& Wiksuana, I. G. B. (2015). Pengaruh ukuran perusahaa, pertumbuhan penjualan dan non-debt tax shield terhadap struktur modal pada perusahaan telekomunikasi di Bursa Efek Indonesia. E-Jurnal Manajemen Unud, 4(5), 1434-1451.

Maulina, G., Nuzula, N. F., \& Nurlaily, F. (2018). Pengaruh faktor-faktor penentu struktur modal terhadap struktur modal (studi pada perusahaan manufaktur yang terdaftar di Bursa Efek Indonesia periode 2014-2016. Jurnal Administrasi Bisnis, 58(1), 156-166.

Putri, J. (2016). Pengaruh struktur modal terhadap nilai perusahaan pada perusahaan manufaktur go public (studi kasus sektor makanan dan minuman. Jurnal Online Mahasiswa FISIP. 3(2), 1-12. 
Ratri, A.M., Christianti, A. (2017) Pengaruh Size, likuiditas, profitabilitas dan pertumbuhan penjualan terhadap struktur modal pada sektor industry properti. Jurnal Riset Manajemen dan Bisnis, 12(1), 1325.

Sari, M. D., Djumahir, Djazuli, A. (2015) Pengaruh profitabilitas, ukuran perusahaan, pertumbuhan penjualan, struktur aset, non-debt tax shield dan usia perusahaan terhadap struktur modal (studi pada perusahaan makanan dan minuman di BEI). Jurnal Ekonomi Bisnis, 20 (1), 22-32.

Sartono, R. A. (2015). Manajemen keuangan:Teori dan aplikasi. Yogyakarta: BPFE

Septiani, N. P. N., \& Suaryana, I. G. N. A. (2018). Pengaruh profitabilitas, ukuran perusahaan, struktur aset, risiko bisnis dan likuiditas pada struktur modal. E-Jurnal Akuntansi Unud, 22(3), 1682-1710.

Shofiyuddin, M. (2015). Analisis pengaruh leverage operasi, pertumbuhan aset dan profitabilitas terhadap struktur modal studi kasus pada perusahaan food and beverages yang terdaftar di BEI. Jurnal Ekonomi dan Bisnis. 16(1), 12-26.

Sitanggang, J.P. ( 2014). Manajemen keuangan perusahaan. Jakarta : Mitra Wacana Media.

Sudana, I. M. (2012). Manajemen keuangan perusahaan teori dan praktik. Jakarta:Erlangga.

Sukandar, B.. M., Achsani, N. A., Sembel, R., \& Sartono, B. (2018). Efisiensi perusahaan konstruksi di Indonesia. Jurnal Ilmiah Manajemen, 8(3), 628 - 63.

Suryaman,Y. A. (2016). Pengaruh profitabilitas, struktur aktiva dan ukuran perusahaan terhadap struktur modal pada perusahaan manufaktur yang terdaftar di Bursa Efek Indonesia. Jurnal Profita, 3, 2-16.

Weston, J.F., \& Copeland, T. E. (2010). Dasar-dasar manajemen keuangan .Jakarta : Erlangga

Widoatmodjo, S. (2012). Cara sehat investasi di pasar modal. Jakarta: PT Elex Media Komputindo.

Yanuardi, A., Hadiwidjojo, D., \& Sumiati. (2014). Faktor determinan atas profitabilitas perbankan yang terdaftar di Bursa Efek Indonesia. Jurnal Akuntansi Multiparadigma, 5(2), 202-218 